This is an Author's Accepted Manuscript of an article published by Edinburgh University Press in Edinburgh Law Review. The Version of Record is available online at: https://www.euppublishing.com/doi/abs/10.3366/elr.2018.0453

\title{
FLOATING CHARGES AND TRUST PROPERTY IN SCOTS LAW: A TALE OF TWO PATRIMONIES?
}

Alisdair D J MacPherson*
A. INTRODUCTION
B. TRUST PROPERTY
C. THE CHARGING OF TRUST PROPERTY
(1) The law of trusts
(2) The law of floating charges
(3) Trustee and registration problems
D. ATTACHMENT AND ENFORCEMENT OF FLOATING CHARGES
(1) Consistency with insolvency law regarding trust property
(2) Beneficial interest
(3) The attachment hypothesis
(4) Truster-as-trustee trust property
(5) Enforcement mechanisms
(6) Ranking
E. CONCLUSION

\section{A. INTRODUCTION}

In Scots law, the trust and the floating charge are two institutions that have been notably influenced by English law. ${ }^{1}$ They are also comparable in a number of other respects. All types of property, capable of being owned, can be secured by a floating charge or held in trust. A trust constitutes a "fund" in which one asset is replaced by another through real subrogation and this also applies to the fluctuating property encompassed by a floating charge. ${ }^{2}$ In addition, like a floating charge, a trust can be used as a security

\footnotetext{
* PhD candidate and Teaching Fellow in Commercial Law, University of Edinburgh. I would like to thank Professor George Gretton, Andrew Sweeney, Scott Wortley and the anonymous peer reviewers for their helpful comments on earlier drafts of this article. I am also grateful for the support provided by the Edinburgh Legal Education Trust.

${ }^{1}$ There is, however, uncertainty regarding the extent to which the origins of trusts law in Scotland are independent from English law: G Gretton, "Trusts" in K Reid and R Zimmermann (eds), The History of Private Law in Scotland: Volume 1 - Introduction and Property (2000) 484ff. See also D J Carr, Ideas of Equity (2017) paras 4-05ff. In this article, "English law" is generally used in a wide sense to include equity.

${ }^{2}$ Regarding real subrogation in trusts, see G L Gretton and A J M Steven, Property, Trusts and Succession, $3^{\text {rd }}$ edn (2017) para 23.6; Gretton (n 1) 484. See R C Nolan, "Property in a fund" (2004) 120 LQR 108 for the view that floating charges and trusts in English law both consist of interests in property in a fund. In Scots law a
} 
device. ${ }^{3}$ Yet there are also significant differences between them. The ways in which they arrived and developed in Scots law are markedly divergent. ${ }^{4}$ And there are also contrasts regarding their integration within the legal system, and with respect to the legal relationships of the parties involved with each. ${ }^{5}$

Understanding the respective natures of trusts and floating charges, and how they operate, obviously assists with determining the content of their interaction. That is certainly true in the present article, which contains an extensive doctrinal analysis of floating charges and trust property in Scots law. It uses the dual patrimony approach of trust law to interpret the floating charge's creation, attachment and enforcement, and thereby demonstrates that it is not possible under the current law to effectively charge property held by a company in trust. Although this conclusion aligns with the orthodox view regarding floating charges over trust property in Scots law, following Tay Valley Joinery Ltd $v$ CF Financial Services $L t d,{ }^{6}$ that view is often expressed with minimal discussion and explanation. ${ }^{7}$ By contrast, this article identifies the application of the dual patrimony theory as a broader foundation explaining the current legal position.

The article also serves an additional purpose. It diagnoses issues that would need to be resolved if the law were to be successfully reformed to enable the charging of trust property. Indeed, the Scottish Law Commission has previously identified certain problems involving floating charges and trust property that would require attention in a reform context, and these are discussed in more detail in this paper. The Scottish Law Commission proposed that such problems would be considered further in the context of their review of the law of trusts. ${ }^{8}$ However, that project has now concluded without any recommendations regarding the charging of property held in trust.

It is unclear how popular allowing a company to create a floating charge over its trust property would actually be, but it would certainly command some support. ${ }^{9}$ And there is undoubtedly a policy argument that can be made in favour of doing so. ${ }^{10}$ Despite floating charges having received much

\footnotetext{
floating charge encompasses changing property but its holder has no real right in the property, at least until attachment.

${ }^{3}$ Clark Taylor \& Co Ltd v Quality Site Development (Edinburgh) Ltd 1981 SC 111 (albeit that the attempt to create a trust in this case failed); Tay Valley Joinery Ltd v CF Financial Services Ltd 1987 SLT 207. And see e.g. Report on Trust Law (Scot Law Com No 239, 2014) paras 2.13ff; W A Wilson and A G M Duncan, Trusts, Trustees and Executors, $2^{\text {nd }}$ edn (1995) ch 4.

${ }^{4}$ The origins of trusts in Scots private law are obscure but date back to the seventeenth century (and beyond): Gretton (n 1). By contrast, floating charges were rejected at common law in Scotland (see Carse v Coppen 1951 SC 233) and were introduced only via the Companies (Floating Charges) (Scotland) Act 1961.

${ }^{5}$ For details of how the trust is conceptualised in Scots law, see the next section.

${ }^{6} 1987$ SLT 207. This case is discussed at various points below.

${ }^{7}$ See e.g. W M Gloag and R C Henderson, The Law of Scotland, $14^{\text {th }}$ edn, by H L MacQueen et al (2017) para 36.03, n 26; G Morse (ed), Palmer's Company Law, 25 ${ }^{\text {th }}$ edn (Looseleaf) (1992-) para 13.402; I M Fletcher and R Roxburgh, Greene and Fletcher, The Law and Practice of Receivership in Scotland, $3^{\text {rd }}$ edn (2005) para 2.42. ${ }^{8}$ Report on Registration of Rights in Security by Companies (Scot Law Com No 197, 2004) para 2.32.

${ }^{9}$ It is noted ibid, para 2.30, that a majority of consultees supported the proposal to allow companies to charge trust property, but some "expressed reservations" and identified difficulties.

${ }^{10}$ It would be possible to write a separate paper on the policy issues involved.
} 
criticism from certain quarters, ${ }^{11}$ they remain widely used and are popular among many practitioners and their clients. A trustee company, without being able to create a floating charge, is highly restricted in terms of the security it can grant over trust property in Scots law (including in comparison to English law). ${ }^{12}$ A common view is that the more security a party can grant over its assets, the greater the likelihood that another party will be willing to lend, and at more favourable rates than would otherwise be the case. ${ }^{13}$ As such, the power to create a floating charge over trust property could allow a trustee to access additional funding, which might help fulfil the trust purposes. (The Scottish Law Commission's proposal to introduce a new non-possessory form of real security over moveables would also assist in this regard. $)^{14}$ In the present writer's view, allowing a professional trustee company to charge its trust property when borrowing for trust purposes would be a broadly acceptable outcome; however, the present article shows that this is not realisable under the current law and highlights doctrinal impediments to the charging of trust property. It also suggests that a prime objective of any reform ought to be coherence with the wider law, and especially with the dual patrimony approach. ${ }^{15}$

\section{B. TRUST PROPERTY}

In a trust, there are three parties: (1) the truster(s); ${ }^{16}$ (2) the trustee(s); and (3) the beneficiary (or beneficiaries). The truster creates the trust and transfers property into it. The trustee holds that property for the benefit of another, the beneficiary, who has a "beneficial interest" in the property. In Scots law a range of views have been advanced over time as to which of the truster, ${ }^{17}$ trustee ${ }^{18}$ and beneficiary ${ }^{19}$ owns the trust property. The established modern view is a formalistic one: the trustee is owner. ${ }^{20}$ Doctrinally, Scots law relies upon personal and real rights to explain the trust, whereas English law uses the divided ownership arising from law and equity; the trustee has legal ownership of trust property

\footnotetext{
${ }^{11}$ See e.g. G L Gretton, "Reception without Integration? Floating Charges and Mixed Systems” (2003) 78 Tulane LR 307; and D Cabrelli, “The Case Against the Floating Charge in Scotland” (2005) 9 EdinLR 407.

${ }^{12}$ These general restrictions on creating security rights over moveable property led to the introduction of the floating charge in 1961: see Law Reform Committee for Scotland, Eighth Report of the Law Reform Committee for Scotland: The Constitution of Security over Moveable Property; and Floating Charges (Cmnd 1017) (1960). ${ }^{13}$ However, for criticism of this view in relation to floating charges in Scots law, see Cabrelli (n 11) at 418ff.

${ }^{14}$ See the Discussion Paper on Moveable Transactions (Scot Law Com DP No 151, 2011). The follow-up report is expected to have been published by the time this article goes to print.

${ }^{15}$ The dual patrimony approach is discussed in Section B.

${ }^{16}$ Also known by the English term "settlor(s)".

${ }^{17}$ At least for certain types of trust, see G L Gretton, "Radical rights and radical wrongs" (1986) Jur Rev 51 and 192.

${ }^{18}$ This is the traditional view espoused by the Institutional Writers: e.g. Stair, Inst, I, 13, 7; Bell, Commentaries, $5^{\text {th }}$ edn (1826) I, 35f. See also the discussion by T B Smith, A Short Commentary on the Law of Scotland (1962) $570 \mathrm{ff}$.

${ }^{19}$ See e.g. Heritable Reversionary Co Ltd v Millar (1892) 19 R (HL) 43 at 46f per Lord Watson, who, in the context of the case, described the beneficiary as "the true owner".

${ }^{20}$ See e.g. Inland Revenue v Clark's Trs 1939 SC 11; Sharp v Thomson 1995 SC 455 per Lord President Hope at 475. Wilson \& Duncan, Trusts (n 3) paras 1-43f, cite other sources supporting this view.
} 
while the beneficiary has equitable ownership. ${ }^{21}$ As property must be transferred into trust to become trust property, it is impossible for the truster to own such property in Scots law, unless they are also a trustee. The beneficiary, meanwhile, has personal rights exercisable against the trustee. ${ }^{22}$ It is clear that if a beneficiary creates a floating charge, its personal rights are part of its property which may be covered and attached by the floating charge. ${ }^{23}$ However, for the purposes of this article, trust property is the property owned (or held) in trust by a trustee.

The established position in Scots law, that a trustee owns the trust property, has been expanded upon in recent times, especially by Professors Gretton and Reid, to explain some of the characteristics of the trust, not least that trust property is protected from the personal creditors of the trustee. ${ }^{24}$ This increasingly accepted view ${ }^{25}$ provides that although a trustee owns trust property it does so in a special trust patrimony, and the beneficiary has personal rights against the trustee in relation to that patrimony. As Carey Miller contends, this special patrimony analysis is used "to preserve the unititular dogma of Scots property law". ${ }^{26}$ It also moves the legal doctrine beyond a simple sui generis description of the rights of parties in a trust. ${ }^{27}$ Identifying a separate patrimony of trust assets and liabilities in addition to a trustee's general (private) patrimony (i.e. the dual patrimony approach) can be helpfully applied when analysing the floating charge's relationship with trust property. And, in terms of integrating the floating charge into wider Scots law, there is, of course, considerable merit in the charge's interaction with trusts aligning with trusts law generally.

As this article progresses, it is useful to have in mind two particular scenarios regarding floating charges and trust property:

Scenario 1: X Ltd grants a floating charge over its property and undertaking to B Bank, to secure a loan. $\mathrm{X}$ Ltd then creates a trust, appointing Y Ltd as trustee and designating Z Ltd as beneficiary. X Ltd

\footnotetext{
${ }^{21}$ For an explanation of legal and equitable ownership in English trusts law, see S Worthington, Equity, $2^{\text {nd }}$ edn (2006) 63ff.

${ }^{22}$ See $\mathrm{n} 18$ and $\mathrm{n} 20$.

${ }^{23}$ Unlike for trustees (see below), there is no separate trust patrimony for the beneficiary's rights in a trust.

${ }^{24}$ See e.g. G L Gretton, "Trust and patrimony" in Scots Law into the $21^{\text {st }}$ Century: Essays in Honour of WA Wilson (ed H L MacQueen), (1996) 182; G L Gretton, “Trusts without equity” (2000) 49 ICLQ 599; K G C Reid, "Patrimony not equity: the trust in Scotland (2000) 8 ERPL 427 updated and republished in R Valsan (ed), Trusts and Patrimonies (2015) 110. For some criticism of the patrimonial approach, see P Matthews, "Square peg, round hole? Patrimony and the Common Law trust” in R Valsan (ed), Trusts and Patrimonies (2015) 62, especially $78 \mathrm{ff}$.

${ }^{25}$ As Reid (n 24) $123 \mathrm{f}$ notes, in Scotland "the central role of patrimony has been accepted by legal scholars, by the Scottish Law Commission, and, increasingly, by the courts, and can now be regarded as 'clearly established'”" As well as the cases cited by Reid (123 at n 55), see Advocate General v Murray Group [2015] CSIH 77; 2016 SC 201 at para 50; and Shenken v Phoenix Life [2015] CSOH 96 at paras 19f. See also the Discussion Paper on The Nature and the Constitution of Trusts (Scot Law Com DP No 133, 2006) paras 2.162.28 and Report on Trust Law (n 3) para 3.4.

${ }^{26}$ D Carey Miller with D Irvine, Corporeal Moveables in Scots Law, $2^{\text {nd }}$ edn (2005) para $12.10 \mathrm{n} 91$.

${ }^{27}$ E.g. in terms of explaining why a beneficiary's personal right has priority over the trustee's personal creditors. For a recent example of the beneficiary's right being considered a right between a personal and a real right, see Joint Administrators of Rangers Football Club plc, Noters [2012] CSOH 55, 2012 SLT 599 per Lord Hodge at para 31. For discussion, see Reid (n 24) at 114f.
} 
transfers property into the trust. Subsequently, B Bank’s floating charge attaches to X Ltd's property and undertaking.

\section{$\underline{\text { Scenario } 1}$}

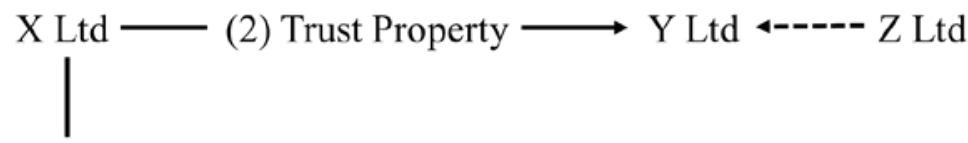

(1) Floating Charge and (3) Attachment
B Bank

Scenario 2: X Ltd creates a trust, appointing Y Ltd as trustee, and designating Z Ltd as beneficiary. X Ltd transfers property into the trust. Subsequently, Y Ltd grants a floating charge over its property and undertaking to B Bank, to secure a loan. ${ }^{28}$ This floating charge later attaches.

\section{$\underline{\text { Scenario } 2}$}

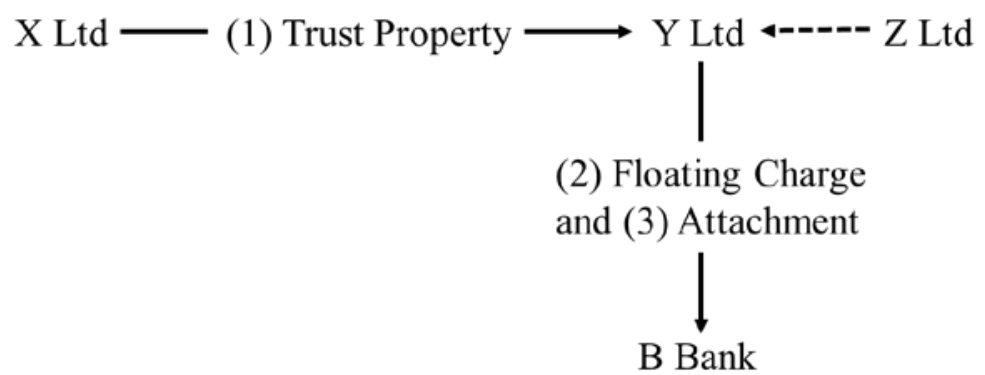

\section{THE CHARGING OF TRUST PROPERTY}

\section{(1) The law of trusts}

Trustees in Scots law can generally grant security rights over trust property where the corresponding borrowing is for the purposes of the trust. This can be specified as a power in the trust deed but is also

\footnotetext{
${ }^{28}$ This borrowing could be for Y Ltd's private purposes, with the corresponding floating charge being created without reference to trust property. Alternatively, the borrowing could be for the trust and an attempt might be made to create the charge expressly over the property held in trust. The implications of this are considered below.
} 
a statutory default power. ${ }^{29}$ There is, therefore, no general rule in the law of trusts which prohibits security rights, including floating charges, from being granted. Indeed, the statutory power refers to the ability to use the "trust estate or any part thereof, heritable as well as moveable" as security. The fact that the whole estate or parts of it can be utilised in this way, rather than only particular items of property, also supports the view that trust law does not preclude the creation of a floating charge over trust property. The wide default powers to borrow and grant security mean that creating security rights is considered a tool to help the trustees fulfil the trust purposes. It would, of course, be possible for a trust deed to exclude the power to create a floating charge. However, a floating charge purportedly created by a trustee, such as in Scenario 2, would be protected from challengers contending that the creation was "at variance with the terms or purposes of the trust". ${ }^{30}$ But neither this nor the express trust purposes are relevant where a charge is created over property by a non-trustee company before that property is transferred into a trust, i.e. a Scenario 1 case. ${ }^{31}$ That is true even if the chargor itself becomes a trustee after the charge's creation.

\section{(2) The law of floating charges}

There is no common law power that enables legal or natural persons to create floating charges in Scots law. It is only due to statutory provision that they can be created by companies and certain other entities. Therefore, only such entities acting as trustees could have the power to grant floating charges over trust property. The Companies Act 1985, s 462(1), provides that a company may create a floating charge "over all or any part of the property... which may from time to time be comprised in its property and undertaking”. Consequently, in determining if trust property is chargeable, the fundamental question is whether trust property is "property... in [the company's] property and undertaking”. Trust property certainly falls within the first usage of "property" in s 462(1); the things (or rights) which can be held in trust are the same things (or rights) which can be property outside the trusts context. The difficulty with s $462(1)$ is whether trust property falls within the second part of the quoted term. ${ }^{32}$ On this point,

\footnotetext{
${ }^{29}$ Trusts (Scotland) Act 1921 s 4(1)(d), gives a general power to trustees "To borrow money on the security of the trust estate or any part thereof, heritable as well as moveable.” See also Gordon v Campbell (1842) 1 Bell's App 428 for a case involving security granted by trustees over property in the trust estate.

${ }^{30}$ Trusts (Scotland) Act $1961 \mathrm{~s}$ 2(1). There would, however, be an ultra vires breach of trust.

${ }^{31}$ W A Wilson, The Scottish Law of Debt, $2^{\text {nd }}$ edn (1991) para 9.18, writes that s 2 of the 1961 Act can only apply where the trust existed when the floating charge was granted. Cf K G C Reid, "Trusts and floating charges” 1987 SLT (News) 113 at 115. See also K G C Reid, The Law of Property in Scotland (1996) para 691.

${ }^{32}$ I.e. whether it is in the company's property and undertaking. In a different context (the registration of charges), the Companies Act 2006 s 859J(1), by referring to a company acting as trustee of "property" or "undertaking", suggests that these terms can include trust property; however, the property or undertaking are crucially not referred to as the company's.
} 
Professor Wilson suggests that although trust assets are, in one respect, the company's property, they may not be "comprised in its property and undertaking". ${ }^{33}$

The instrument creating a floating charge specifies the property over which the floating charge is created, up to a maximum of all property in the company's property and undertaking. With respect to trust property, there are three possibilities. Firstly, the instrument can expressly exclude trust property, in which case the floating charge undoubtedly does not cover such property. Secondly, the instrument can omit mention of trust property. If so, it also seems that property held in trust is not charged. In Tay Valley Joinery Ltd v CF Financial Services Ltd ${ }^{34}$ a floating charge was granted over the whole property of Tay Valley Joinery Ltd (TVJL). ${ }^{35} \mathrm{~A}$ few days later, TVJL entered into an invoice discounting agreement for present and future book debts, in the form of a contract of sale, but without formal assignation. The Second Division decided that the agreement was a valid declaration of trust under Scots law and had been intimated to the beneficiary (the defender). ${ }^{36}$ In addition, TVJL intimated details of the book debts to the beneficiary on an ongoing basis, which was sufficient to transfer newly arising debts into the trust. ${ }^{37}$ As TVJL held the book debts in trust, the court determined that they were not attached by a pre-existing floating charge, when joint receivers were appointed to TVJL's whole property and undertaking. Given that the maximum extent of a charge is the same as regards its creation and attachment (the company's property and undertaking), ${ }^{38}$ the case indicates that a party granting a floating charge over all the property in its property and undertaking, without express mention of trust property, is doing so for non-trust property only. ${ }^{39}$

The third possibility is that the floating charge instrument expressly includes trust property. The consequences of this were not considered in Tay Valley. Commentators have, however, interpreted the case widely, and there appears to be a general view that trust property cannot be the subject of a floating charge in any circumstances. ${ }^{40}$ But this is often asserted without explanation and without consideration of what the outcome would be if an attempt were made to expressly charge trust property. Let us imagine a Scenario 2 case in which property has been transferred to a professional trustee company, Y Ltd, acting solely as a trustee. ${ }^{41}$ The company wishes to raise finance to help fulfil the trust purposes and it

\footnotetext{
${ }^{33}$ Wilson, Debt (n 31) para 9.18. He adds that it is "of course always possible to deal with the matter expressly in the instrument of the charge". What he means here is unclear, especially if trust property is expressly included in the instrument.

341987 SLT 207.

${ }^{35}$ The case involved the Companies (Floating Charges and Receivers) (Scotland) Act 1972 (ss 11 and 13(7)) but the relevant provisions were substantially the same as the current provisions.

${ }^{36}$ Although the invoice discounting agreement in Tay Valley was expressly to be governed by English law, the question of which Scottish assets were attached was to be determined by Scots law: see e.g. per Lord Robertson at 211.

${ }^{37}$ Tay Valley per Lord Dunpark at 216 and per Lord Robertson at 213.

${ }^{38}$ For attachment, see Companies Act 1985 s 463(1); Insolvency Act 1986, ss 53(7), 54(6) and Sch B1, para 115(1B) and (3).

${ }^{39}$ The case is discussed further below in relation to attachment and truster-as-trustee trusts.

${ }^{40}$ See e.g. $\mathrm{n} 7$ above. Cf Reid (n 31), who disagrees with the decision in Tay Valley. Reid's view is discussed further below in the context of truster-as-trustee trusts.

${ }^{41}$ Companies are frequently established solely for the purpose of acting as a trustee.
} 
seeks to create a floating charge in favour of a lender. Y Ltd could state in the charge instrument that it is acting as trustee of a specific existing trust and that only property it owns as trustee is charged. Furthermore, the limitation of the intended charge to trust property would be identifiable to third parties from the copy of the instrument accessible from the charges register. ${ }^{42}$ This situation differs from the one in Tay Valley in various respects and it is not inconceivable that a court could accept the validity of a floating charge over trust property in such circumstances. Yet it would be a mistake for it to do so.

It is true that, in general terms, a trustee may contract with a creditor to the effect that trust assets, rather than personal assets, are to be used to satisfy the claim of the creditor. ${ }^{43}$ And it might be argued that such freedom should also apply to the company when it charges its property. But if the whole property and undertaking of the company represents the statutory maximum of a floating charge's extent, and this does not include trust property (as in Tay Valley), then how can expressly including trust property expand the floating charge's ambit? There is no obvious satisfactory answer to this.

The application of the dual patrimony approach to the interpretation of "[the company's] property and undertaking” justifies the outcome in Tay Valley, as regards the property escaping the charge's ambit following its transfer into the trust, ${ }^{44}$ and suggests that it is never possible for a floating charge to encompass trust property. If a charge granted over all of the property and undertaking does not cover property in a trust patrimony then only property in the company's general patrimony can ever be charged. And whenever the chargor transfers property out of its general patrimony, the charge ceases to affect that property. The Companies Act 1985, s 462(1), seems to presuppose that a company only has one property and undertaking for floating charge creation purposes. Consequently, there is no scope to argue that a company, in its capacity as a trustee, has a separate property and undertaking for trust property. However, one might contend that if a company is established solely for the purpose of being a trustee and only engages in business for the trust, then the company's only property and undertaking corresponds to property in its trust patrimony. But this would be incorrect, as the company's general patrimony still exists; it is the default patrimony and the company has the capacity to hold property in it, even if it is inactive.

Consistency of interpretation with related legislative terms, discussed at section D below as regards attachment and enforcement, also supports the view that a company’s property and undertaking is limited to its general patrimony. Nevertheless, identifying the potential for a separate property and undertaking suggests a possible route for reforming the law to accommodate floating charges over trust property. Given the distinction between general and trust patrimonies in wider law, it would be sensible

\footnotetext{
42 The company could even provide a statement to the registrar specifying that it is a trustee: Companies Act 2006 s $859 \mathrm{~J}(1)$.

${ }^{43}$ See Gordon v Campbell (1840) 2 D 639, affd (1842) 1 Bell’s App 428; Cullen v Baillie (1846) 8 D 511; Lumsden v Buchanan (1865) 3 M (HL) 89 per Lord Cranworth at 95. Also see Cunningham v Montgomerie (1879) 6 R 1333; J St Clair and J Drummond Young, The Law of Corporate Insolvency in Scotland, $4^{\text {th }}$ edn (2011) para 12.33; R G Anderson, "Introduction to Juristic Persons”, in I G MacNeil (ed), Scots Commercial Law (2014) paras 1.12 and 1.15.

${ }^{44}$ No view is expressed here regarding the validity of the trust itself in Tay Valley.
} 
for reform in this area to adhere to such separation. To enable a floating charge to extend from one patrimony into another would be complicated in various respects, including in relation to the allocation of loans (secured by the charge) to the different patrimonies, ranking against competing rights, issues of enforcement and, potentially, publicity to third parties. Another reason why the decision in Tay Valley was justified was because it avoided these very issues.

The most appropriate approach for reform would be to allow for the charging of trust property only where the charge is created expressly over property held in a specified trust that already exists (e.g. a charge created by Y Ltd in the version of Scenario 2 outlined above). Using a patrimonial analysis, combined with a distinction between a general property and undertaking and a trust one, to underpin any reform in the law would make it simple to determine when property leaves the ambit of a charge over trust property: any transfer out of the trust patrimony would mean the property was no longer covered by the charge. This would also apply even if the property was sold and transferred into the trustee's general patrimony. ${ }^{45}$ The charge would, however, encompass money or other property received in payment for that transferred property.

\section{(3) Trustee and registration problems}

The Scottish Law Commission has noted that attempting to facilitate floating charges over trust property also raises questions as to whether and how a plurality of trustees (including non-corporate trustees) could grant a charge and how the replacement of the chargor as a trustee could and should be dealt with. ${ }^{46}$ This section gives further consideration to these matters.

A floating charge is a security interest granted by one company over its own property. However, for a trust there can be multiple trustees. So, if a floating charge could be created in Scenario 2 by Y Ltd over its trust property, how would this work where it was one of a number of trustees (e.g. alongside Y2 and Y3)? Trustees have joint ownership of trust property, so each trustee has a shared title to the whole of each item of property. ${ }^{47}$ However, in contrast to where a party owns property in common, $\mathrm{Y}$ Ltd does not have a severable ownership right in the property that it owns jointly. This means that $\mathrm{Y}$ Ltd could not unilaterally create a floating charge over trust property, if there were additional trustees.

\footnotetext{
${ }^{45}$ Or presumably into another one of its trust patrimonies, if it was trustee for multiple trusts. A transfer into a trustee's general patrimony would be a breach of fiduciary duty. However, such a transaction could be authorised by the trust deed or the beneficiaries (for discussion and sources, see Discussion Paper on Breach of Trust (Scot Law Com DP No 123, 2003), paras 4.2-4.6).

${ }^{46}$ Report on Registration (n 8) para 2.32. Cf Law Reform Committee, Twenty-Third Report: The Powers and Duties of Trustees (Cmnd 8733) (1982) para 2.20, regarding English law.

${ }^{47}$ See e.g. Gordon's Trustees v Eglinton (1851) 13 D 1381 per Lord Justice-Clerk Hope at 1385; and the discussion and authorities cited at Reid, Property (n 31) paras 34ff. See also D Kleyn and S Wortley, "Coownership” in R Zimmermann, D Visser and K Reid, (eds) Mixed Legal Systems in Comparative Perspective: Property and Obligations in Scotland and South Africa (2004) 704ff.
} 
Even with the agreement and execution of a majority, or all, of the trustees there would be problems. ${ }^{48}$ Any person, whether natural or juristic, may have the power to grant fixed securities but floating charges can only be created by certain corporate entities. Thus, if Y2 and Y3 are natural persons, they would have no power to create a floating charge, and so a charge could not be created collectively by the trustees. In fact, it is not even possible under the current law to create a combined floating charge where Y Ltd, Y2 and Y3 are all companies (and it is unclear, in any event, when this would be of any value outside the context of trusts). For joint property, such as trust property, there is merely a single title, and the grant of a valid subordinate right in the property probably requires all owners to participate in the grant. ${ }^{49}$ Consequently, reform would be required to enable multiple companies to jointly grant the same floating charge. The registration of charges regime, which involves registration against a particular company, would also need to be amended to accommodate the registration of such a charge.

There has been doubt as to whether the registration of charges requirements in the Companies Acts even apply to "charges” (of any kind) granted by a company in its capacity as a trustee. ${ }^{50}$ The nonapplication of registration provisions would be especially problematic with a floating charge, as the only publicity regarding its creation is provided by its registration in the charges register. Nevertheless, securities granted by trustee companies have often been registered as a precaution. And under the current regime, ${ }^{51}$ it is possible (but not obligatory) for a statement to be delivered to the registrar specifying that the grantor company is acting as a trustee. ${ }^{52}$ This shows that security granted over a company's trust property is capable of being registered. Furthermore, Professor Gullifer has rightly suggested that requiring registration of such "charges" (for them to be effective) is "the better view" in practical and policy terms. ${ }^{53}$ This should be considered to represent the current law.

Even if a floating charge could be validly created over trust property, there might be other inherent risks to a creditor if they chose to accept such a charge. If there was only one chargor, such as Y Ltd, and it resigned or lost its position as trustee, the floating charge would no longer cover the trust property. This would be true whether Y Ltd had been a joint trustee or a sole trustee. The result would be appropriate given that the charge would be registered against Y Ltd, and so would no longer be identifiable by third parties dealing with the trust and its trustee(s) ${ }^{54}$ It demonstrates the important point

\footnotetext{
48 The default rule is that a decision is made by a quorum, which is a majority of trustees: Trusts (Scotland) Act $1921 \mathrm{~s} 3(\mathrm{c})$. It is unclear whether execution by a majority or all trustees is required for a conveyance: see Harland Engineering Company v Stark's Trustees 19142 SLT 292. This is also the case for the granting of a security.

${ }^{49}$ See e.g. Reid, Property (n 31) para 36 and n 48.

${ }^{50}$ L Gullifer (ed), Goode on Legal Problems of Credit and Security, $5^{\text {th }}$ edn (2013) para 2.22.

${ }^{51}$ Companies Act 2006 ss 859A-859Q.

52 Companies Act 2006 s 859J(1).

${ }^{53}$ Gullifer, Legal Problems (n 50) para 2.22. Companies Act 2006 s 859A(1) refers to a company creating a charge, with no distinction as to whether or not it holds the charged property in trust. Thus, various securities created by Scottish companies acting as trustees must also be registered to make them effective.

54 The Companies Act 2006 s 859C could, however, allow for registration of the charge against a replacement corporate trustee, but it is unclear how this provision applies to floating charges.
} 
that a floating charge would not be a security over the trust or the trust property itself, but a security over the property which the chargor holds in trust when attachment occurs.

Interestingly, the wording of the Trusts (Scotland) Act 1921, s 20, regarding the effect of the resignation of a trustee, bears some comparison to the references to "property and undertaking" in the floating charges legislation: “... such trustee shall be thereby divested of the whole property and estate of the trust, which shall accrue to or devolve upon the continuing trustees or trustee...”. The express inclusion of property and estate "of the trust" contrasts with the absence of a trust reference in the floating charges legislation, which again indicates that the company's property and undertaking only relates to its general patrimony.

Bearing in mind the potential hazards if a trustee chargor leaves its position as trustee, an intending chargeholder could require agreement from the chargor (and other trustees) that its permission would be sought, or it would at least be informed, if the chargor wished to resign or was to be removed. ${ }^{55}$ This would, however, only be contractual and, unlike the position in England, automatic crystallisation clauses are ineffective: ${ }^{56}$ the only attachment events in Scotland are the ones specified in the legislation. ${ }^{57}$ One solution would be to legislate to give effect to automatic attachment clauses, while another would be to create a further attachment event, which would take place the moment before a chargor ceases to be a trustee. ${ }^{58}$ However, these forms of attachment could inhibit the successful operation of the trust and there might be related enforcement and publicity issues. If, instead, chargeholders were just expected to accept the risk that if the chargor lost its status as a trustee, then the charge would no longer cover the property, this might undermine the appeal of taking a floating charge over trust property.

The most effective system would allow a creditor to obtain a floating charge over all or any of the property in the trust from time to time, rather than the trust property of a particular trustee. If a trust had separate legal personality and could create a floating charge (and this could be registered against the trust), it would enable multiple trustees, including non-corporate trustees, to create the charge and would mean that the charge would continue to affect trust property even if the original chargor was replaced as a trustee. However, trusts in Scotland are not legal persons, within the registration of charges regime or elsewhere. Importantly, there is a contrast between the nature of the trust patrimony and our current conception of a floating charge, as a security connected to the patrimony of a single nonreplaceable chargor, including as regards registration. Without the possibility of a floating charge being

\footnotetext{
${ }^{55}$ For details regarding the resignation and removal of trustees, see Report on Trust Law (n 3) paras 4.10ff.

${ }^{56}$ There are difficulties regarding floating charges over trust property in English law, including in relation to the replacement of the chargor as trustee; however, it seems that it may be possible to circumvent these issues: D Hayton (general ed) with P Matthews and C Mitchell, Underhill and Hayton, Law Relating to Trusts and Trustees, $19^{\text {th }}$ edn (2016) paras 81.54ff.

${ }^{57}$ For English law, see e.g. Gullifer, Legal Problems (n 50) paras 4-53ff; W J Gough, Company Charges, $2^{\text {nd }}$ edn (1996) 137 and ch 11.

${ }^{58}$ The attachment would also need to be connected to a particular enforcement process.
} 
created and registered in relation to the trust patrimony (irrespective of the identity of trustees at a given time), the value of enabling the charging of trust property would seem to be diminished.

\section{ATTACHMENT AND ENFORCEMENT OF FLOATING CHARGES}

The attachment of a floating charge is tied to the property the chargor owns when attachment occurs (as limited by the property charged by the relevant instrument). This explains why a floating charge created by X Ltd in Scenario 1 does not attach to property it has already transferred into trust. For Scenario 2 cases, more detailed consideration is required as to whether trust property is property in Y Ltd's "property and undertaking”. As mentioned above, there is consistency in language between the provisions for the creation and attachment of a floating charge. ${ }^{59}$ Clearly then, if a charge cannot be created over trust property, attachment to such property is also not possible. Yet the specific analysis of attachment is also worthwhile as, conversely, it gives us further evidence as to whether or not trust property can be successfully charged in Scots law.

The present section demonstrates that the use of the dual patrimony thesis and previous authority regarding trust property in insolvency supports the view that such property cannot be attached by a floating charge. And, as will be discussed, this extends to truster-as-trustee trusts. The section also considers whether the concept of beneficial interest could hinder the attachment of trust property and other more hypothetical issues, such as how a floating charge over trust property could be enforced, and how an attached charge might rank against competing rights.

\section{(1) Consistency with insolvency law regarding trust property}

A floating charge attaches to property in the context of the insolvency-related processes of liquidation, receivership and administration. As already noted, it was held in Tay Valley ${ }^{60}$ that a floating charge over the whole of a company's property did not include property subsequently transferred into a trust, of which the company was sole trustee. Consequently, the trust property was not attached by the charge upon the chargor entering receivership. The position is consistent with case law involving trusts within an insolvency context. In Heritable Reversionary Co Ltd v Millar ${ }^{61}$ the House of Lords decided that the term "whole property of the debtor" (and related wording) in bankruptcy legislation did not include property held by the debtor in trust (including a latent trust), and such property was therefore protected

\footnotetext{
${ }^{59}$ As regards liquidation, the Companies Act 1985 s 463(1), provides that a floating charge granted by a company entering that process attaches to "the property then comprised in the company's property and undertaking” or part thereof. For attachment in receivership, see Insolvency Act 1986 s 53(7) and s 54(6); and for attachment in administration, see Insolvency Act 1986, Sch B1, para 115(1A)-(1B) in combination with para 65(3)(b); and Sch B1, para 115(2) and (3). See also the text corresponding to $n 111$ below.

601987 SLT 207.

${ }^{61}$ Heritable Reversionary Co Ltd v Millar (1892) 19 R (HL) 43.
} 
from that party's personal creditors. ${ }^{62}$ If “[the company's] property and undertaking” has an equivalent meaning, then trust property is not attachable by a floating charge.

In contrast to the position for sequestration in the current bankruptcy legislation, ${ }^{63}$ trust property is not expressly excluded from the property included within a liquidation. It is, however, generally accepted that trust property does not fall within the meaning of the company's "property" available to a liquidator. ${ }^{64}$ Indeed, it is difficult to understand how certain liquidation provisions would operate if trust property was included. ${ }^{65}$ Very similar statutory language is used for the related processes of receivership and administration, which indicates that there is consistency in meaning across the different processes. ${ }^{66}$

Before Tay Valley, Halliday suggested that the express creation of a trust to enable a purchaser to hold goods for a seller until payment ${ }^{67}$ "would be valid in a question" between the seller (as beneficiary) and inter alia a liquidator or receiver of the purchaser. ${ }^{68}$ Tay Valley affirms the correctness of the view that a floating charge attaching in receivership will not affect trust property. Related to this, St Clair and Lord Drummond Young also consider that "property" subject to the floating charge (in the Companies Act 1985 and the Insolvency Act 1986) excludes trust property, as it has the same meaning outlined by Lord Watson in Heritable Reversionary, ${ }^{69}$ which they deem to have wide-ranging applicability to insolvency regimes. ${ }^{70}$ In addition, they state that a floating charge's nature means its holder expects property to be alienated and a trust is a mechanism for doing so. In their view, the trust should still have priority where it is latent and was created before a floating charge; the floating charge does not create real rights in particular items of property and there is an assumption that property may be alienated by the company. ${ }^{71}$ However, an existent latent trust is not akin to a future alienation but,

\footnotetext{
${ }^{62}$ The term was used in the Bankruptcy (Scotland) Act 1856 s 102, in the context of property vesting in the trustee in sequestration. For the corresponding terms in earlier legislation, see Heritable Reversionary per Lord Herschell at 45 and per Lord Watson at 50. For the legal position before Heritable Reversionary, see e.g. $\mathrm{H}$ Goudy, A Treatise on the Law of Bankruptcy (1886) at 252 and 285f and his case note at (1891) Jur Rev 365 critiquing the First Division's decision in Heritable Reversionary. (Goudy later acted for the successful appellants in the House of Lords). The current equivalent legislative term is "whole estate of the debtor": Bankruptcy (Scotland) Act 2016 s 78(1).

${ }^{63}$ Bankruptcy (Scotland) Act 2016 s 88(1)(c).

${ }^{64}$ See Turnbull v Liquidator of Scottish County Investment Co 1939 SC 5; Smith v Liquidator of James Birrell Ltd (No 2) 1968 SLT 174; and Gibson v Hunter Home Designs Limited 1976 SC 23. See also Bank of Scotland v Liquidators of Hutchison, Main, \& Co Ltd 1914 SC (HL) 1. For current legislative provisions referring to the company's “property”, see e.g. Insolvency Act 1986 ss 107, 144, 145 and Sch 4, para 6.

${ }^{65}$ E.g. Insolvency Act 1986 ss 107 and 127; and see St Clair \& Drummond Young, Corporate Insolvency (n 43) para 12-01, n 4.

${ }^{66}$ See the section on enforcement mechanisms below.

${ }^{67}$ There seems no good reason to distinguish here between this type of trust and the type in Tay Valley.

${ }^{68}$ J H Halliday, Conveyancing Law and Practice, vol 1, (1985) 296. See also the discussion of Halliday's position at Wilson \& Duncan, Trusts (n 3) paras 4-16f.

${ }^{69}$ At $49 \mathrm{f}$.

${ }^{70}$ St Clair \& Drummond Young, Corporate Insolvency (n 43) para 12-03.

${ }^{71}$ Ibid. The authors (at para 12-03, n 26) compare the position for floating charges with Lord Watson's views in Heritable Reversionary at 47, where he states that "Personal creditors of the trustee who neither stipulate for nor obtain any conveyance to [the trust estate] do not, in the sense of law, transact on the faith of its being the property of the trustee."
} 
rather, an earlier alienation. If the question of whether a floating charge can attach to property is dependent upon the holder's expectations of future dealings by the debtor, the pre-existence of a latent trust seems to be of little relevance. A patrimonial explanation seems more appropriate; the floating charge is only created over property in the general patrimony (from time to time), it does not create real rights in property before attachment and cannot attach to property outside the general patrimony. This serves to align the floating charge with the patrimonial distinction that exists in insolvency law: ${ }^{72}$ the context in which the charge attaches.

\section{(2) Beneficial interest}

A related issue is the role that beneficial interest plays in preventing a charge from attaching to trust property. In Sharp v Thomson ${ }^{73}$ Lords Clyde and Jauncey used Heritable Reversionary to help interpret the meaning of the company's "property" (and undertaking) in the floating charges legislation and thereby identified the chargor's holding of beneficial interest as a condition for attachment. ${ }^{74}$ Similarly, in Tay Valley, the transfer of beneficial interest ("beneficial ownership") was considered to prevent the attachment of a floating charge. ${ }^{75}$ The meaning of "beneficial interest" as regards floating charges is nebulous. However, the term is clearer in trusts law: it corresponds to the beneficiary's interest in the trust. When Sharp was decided this was more likely to be considered a sui generis personal right. ${ }^{76}$ Now, the dual patrimony approach characterises the beneficial interest as a personal right relating to the trustee in its trust patrimony. ${ }^{77}$ In any event, and as noted by Wortley, requiring a chargor to have beneficial interest for a charge to attach means a trust beneficiary will always defeat a chargeholder under the current law, as only the beneficiary will have beneficial interest. ${ }^{78}$ The beneficiary does not succeed by virtue of ranking. Rather, the floating charge does not attach to the property at all, and therefore the chargeholder has no right in the property. ${ }^{79}$

This raises the further question of whether beneficial interest would present an obstacle to a reformed law that sought to give a trustee company the power to create a floating charge expressly over

\footnotetext{
${ }^{72}$ See the section on enforcement mechanisms below (D(5)) for more details.

${ }^{73} 1997$ SC (HL) 66.

${ }^{74}$ Sharp did not, however, involve the creation of a trust: per Lord Clyde at 85.

${ }^{75}$ Tay Valley per Lord Robertson at 210f, per Lord Dunpark at 214 and per Lord McDonald at 219.

${ }^{76}$ See e.g. Smith, Short Commentary (n 18) at 570ff; Reid, Property, para 10. This could also have been described (per Tony Honoré) as a "protected" personal right: see Reid (n 24) at 115.

${ }^{77}$ Albeit that its ranking seems to be postponed (see below).

${ }^{78}$ Assuming the trust was created before the charge's attachment. S Wortley, "Squaring the circle: revisiting the receiver and 'effectually executed diligence'” (2000) Jur Rev 325 at 332f. However, it would be possible for a charge to attach to the "beneficial interest" if the chargor was, instead, a beneficiary.

${ }^{79}$ Analysing the matter in this way also avoids the possibility of the circle of priority, outlined by Wortley (n 78) at 329ff, involving arrestment, a floating charge, and a trust. This is because the charge does not attach and so the ranking is only between the beneficiary's right and the arrestment. The "circle" would also now be resolved on the basis of ranking alone by MacMillan v T Leith Developments Ltd [2017] CSIH 23; 2017 SLT 415, which indicates that a bare arrestment would rank ahead of the floating charge (and the trust beneficiary would also prevail against the charge).
} 
trust property. After all, a trustee company would never have such interest. Yet, even without a statutory provision specifying that beneficial interest would not be a necessary condition in those circumstances, it seems unlikely that attachment would be hindered. This is especially true if we consider that beneficial interest would probably not have been the determining factor in Heritable Reversionary if the creditors were trust creditors and it was the trust estate that was sequestrated ${ }^{80}$ Instead, despite the trustee not having beneficial interest, it is likely that the creditors would have had valid claims against the trust estate. ${ }^{81}$ This would certainly be the case under the current law as, although trust property is excluded from the property that ordinarily vests in a trustee in sequestration, ${ }^{82}$ a trust estate can be separately sequestrated, ${ }^{83}$ and the trust creditors are ranked in relation to that estate.

The absence of beneficial interest in the debtor does not therefore exclude trust creditors. The actual result of beneficial interest residing in another party is that property is outside the debtor's general patrimony (and associated insolvency processes) and is protected from the debtor's personal creditors. Applied to the floating charge after Sharp, beneficial interest (in the trusts sense) is only an attachment condition if the charge has been created over property that is not held in trust. It is true that property and undertaking apparently excludes trust property under the current law. ${ }^{84}$ But if there was a distinct trust property and undertaking, corresponding to the company's trust patrimony, the absence of beneficial interest in the trustee company would not preclude a charge's attachment to such property.

\section{(3) The attachment hypothesis}

If a trust property and undertaking did exist, the prevailing interpretation of the attachment "statutory hypothesis" (that a floating charge attaches as the relevant form of voluntary fixed security for the property in question) ${ }^{85}$ would generally be unproblematic as trustees (usually) have the power to grant fixed securities. Using this hypothesis, it might be thought that, even under the present law, the position of the chargeholder would be equivalent to a good faith acquirer of security for value. ${ }^{86}$ In Tay Valley an argument was made, along these lines, to support the chargeholder having priority over the latent

\footnotetext{
${ }^{80}$ One difference between a latent trust, as in Heritable Reversionary, and a non-latent trust is that it is more difficult for parties to be trust creditors in relation to the former, as they may not be aware of the latent trust and the default patrimony affected by a debt is the general patrimony.

${ }^{81}$ This is an application of the existence of separate trust debts.

${ }^{82}$ Bankruptcy (Scotland) Act 2016 s 88(1)(c). The same applies in English law: Insolvency Act 1986 s 283(3)(a).

${ }^{83}$ Bankruptcy (Scotland) Act 2016 s 6(1)(a) (and see n 116 below).

${ }^{84}$ Following Sharp, the company's property and undertaking is a narrower concept than all of the property within that party's general patrimony: property can leave the property and undertaking prior to ownership being transferred while such property will remain in the general patrimony until the transfer is completed.

${ }^{85}$ See Companies Act 1985 s 463(2); Insolvency Act 1986 ss 53(7) and 54(6); Sch B1, para 115(4); Forth \& Clyde Construction Co Ltd v Trinity Timber \& Plywood Co Ltd 1984 SC 1.

${ }^{86}$ For the implications of being a good faith acquirer for value from a trustee, see St Clair \& Drummond Young, Corporate Insolvency (n 43) para 12-01. Reid (n 31) at 115 argues that this rule has been replaced for trusts by s 2 of the 1961 Act, which does not require good faith.
} 
trust. ${ }^{87}$ The court did not, however, decide the point, as the matter had not been raised in the stated case. In reality, the issue is irrelevant for determining whether the chargeholder prevails against a beneficiary. Logically, the attachment effect can only arise upon attachment taking place and, if that occurs, the floating charge, as security in the property, will automatically rank ahead of the beneficiary's personal rights. ${ }^{88}$ The key point, therefore, is whether trust property is attached and the evidence shows that attachment is not possible under the current law.

\section{(4) Truster-as-trustee trust property}

Although truster-as-trustee trusts have been impliedly included in the discussion above regarding the wider implications of Tay Valley, they also merit special consideration here. ${ }^{89}$ A competition between a floating charge and a truster-as-trustee trust arises where property is charged but is then moved into such a trust; the chargor remains owner, but it instead holds the property in its capacity as trustee. The principal issue for floating charge purposes is whether this is a sufficient transfer to render the charge unattachable to the property.

Of course, if an attempt to establish a truster-as-trustee trust failed, the floating charge would attach to the property, as the latter would continue to belong to the chargor in that party's general capacity. Despite the Second Division's recognition of the validity of the truster-as-trustee trust in Tay Valley, there remains uncertainty as to the circumstances in which this type of trust will be considered valid in Scots law within a commercial context. ${ }^{90}$ In the earlier case of Clark Taylor ${ }^{91}$ the First Division had rejected the argument that a trust had been created, despite acknowledging that commercial trusteras-trustee trusts could be created in Scots law. Perhaps surprisingly, since Tay Valley there has been little case law to further explain the legal position. ${ }^{92}$ Commercial truster-as-trustee trusts remain controversial on policy and doctrinal grounds. ${ }^{93}$ A registration requirement would alleviate concerns

\footnotetext{
${ }^{87} 1987$ SLT 207 at 219. This was argued using the authority of Redfearn $v$ Somervail (1813) 1 Dow 50, 1 Pat App 707 and Burns v Lawrie's Trs (1840) 2 D 1348.

${ }^{88}$ See the section below on ranking for further details.

${ }^{89}$ The focus is on trusts in which the truster makes itself the sole trustee of the created trust. Allan's Trs $v$ Inland Revenue 1971 SC (HL) 45 definitively established the legitimacy of truster-as-trustee trusts and provided that intimation to at least one of the beneficiaries is equivalent to delivery. See also Clark Taylor (n 3) per Lord President Emslie at 118; and Tay Valley (n 3) especially per Lord Robertson at 211f. And see K G C Reid, "Constitution of trust" 1986 SLT (News) 177 for discussion about the meaning of "delivery".

${ }^{90}$ Including when they are being used for security purposes. On a related note, the transfer of property into such trusts could be a gratuitous alienation in certain circumstances, but it is unclear when precisely that will be the case. It is not possible to discuss this further here.

${ }^{91} 1981$ SC 111.

${ }^{92}$ See Report on Trust Law (n 3) para 2.12ff for details of the commercial usage of trusts in recent decades. See also D Cabrelli, "Can Scots lawyers trust Don King? Trusts in the commercial context” 20016 SLPQ 103. For discussion of Tay Valley and earlier cases, see e.g. G L Gretton, "Using trusts as commercial securities" (1988) 33 JLSS 53; D P Sellar, "Trusts and liquidators - further thoughts” 1988 SLT (News) 194; K G C Reid, "Trusts and liquidators - a reply" 1988 SLT (News) 365; and D P Sellar, "Letter to the editor" 1989 SLT (News) 143.

${ }^{93}$ See Clark Taylor per Lord President Emslie at 115f; Wilson \& Duncan (n 3) para 4-18; J Macleod, "General Principles of Property Law”, in I G MacNeil (general ed), Scots Commercial Law (2014) paras 11.91ff. See also
} 
relating to the absence of publicity when property is moved into such a trust but this has been rejected by the Scottish Law Commission. ${ }^{94}$

As regards registration and publicity, there is a possibility that the creation of a truster-as-trustee trust for security purposes, by a company, is a registrable charge under the Companies Act 2006, s 859A. ${ }^{95}$ A registration requirement would provide notice of the trust to third parties dealing with the company and would mean the register provides a more comprehensive impression of the securities created by the company. The viewpoint is supported by the fact that such a trust in English law would need to be so registered and the charges regime is now UK-wide. ${ }^{96}$ In addition, the creation of a trust for security purposes is a "right in security" in Scots law in the broad sense of the term, just like assignation in security, which is identified in the legislation as a charge but is a transfer of property for security purposes rather than a real right in security. ${ }^{97}$ If a trust created for security purposes is a charge, the failure to register it would render it void against any liquidator, administrator or creditor of the company, ${ }^{98}$ and would therefore mean the floating charge could attach to the property. However, considering a security trust to be a registrable charge is at odds with existing practice as well as the accepted understanding of the law under the previous registration regimes. A decision in line with the alternative view would be highly controversial and unpopular in certain quarters and could raise doubts about many previous security trust transactions. In statutory interpretation terms, the more conservative view could be justified by considering "right in security" in the legislation ${ }^{99}$ to mean only a real right in security (thus excluding trusts), with assignation in security merely being an express exception to this. Consequently, each argument has its merits and it is difficult to take a concluded position on the issue.

\footnotetext{
e.g. Gretton (n 92) at $53 \mathrm{f}$ who argues for the identification of public policy restrictions on the use of trusts as securities. St Clair \& Drummond Young, Corporate Insolvency (n 43) paras 12-14ff, suggest that the trust must represent "an underlying commercial or economic reality" and is unlikely to do this where the subjects selected are of a fluctuating nature, e.g. stock-in-trade. In such cases the trust is likely to amount to an attempt to create a floating charge by means other than the Companies Act 1985 s 462.

${ }^{94}$ One of the proposals in the Discussion Paper on the Nature and the Constitution of Trusts (n 25) paras 4-16ff, was that truster-as-trustee trusts would only be valid if registered in a public register. However, as noted in the subsequent Report on Trust Law (n 3) para 3.11, consultees opposed any change in the law and the Scottish Law Commission consequently decided that any change would be "highly undesirable".

${ }^{95}$ Relevant charge documentation requires to be delivered to the registrar of companies within 21 days from the day after the creation date of a charge (s 859A(4)). And see s 859E for the date of creation. For the previous regime for Scottish-registered companies, see the (now-repealed) ss 878-892 of the Companies Act 2006.

${ }^{96}$ It is even possible for a trust to be considered a floating charge in English law. For the position in England, see E McKendrick, Goode on Commercial Law, $5^{\text {th }}$ edn (2016) paras 22.16, 22.24f and 24.30f; Gullifer (ed), Legal Problems (n 50) para 1-57. See also e.g. Gray v G-T-P Group Ltd Re F2G Realisations Ltd (In Liquidation) [2011] BCC 869.

${ }^{97}$ Companies Act 2006 s 859A(7)(b). For the nature of assignation in security in Scots law, see e.g. Discussion Paper on Moveable Transactions (n 14) para 7.6; R G Anderson, Assignation (2008) para 7-36; and G L Gretton, "The Concept of Security” in D J Cusine (ed), A Scots Conveyancing Miscellany: Essays in Honour of Professor J M Halliday (1987) 130.

${ }^{98}$ Companies Act 2006 s 859H(3).

${ }^{99}$ In the Companies Act 2006, s 859A(7)(b).
} 
In any event, if a truster-as-trustee trust is validly created, the consequences of this seem to fit with the idea that property is transferred out of the company's property and undertaking, thereby removing the possibility of attachment. In Clark Taylor, Lord President Emslie suggested that the steps necessary to establish a truster-as-trustee trust would lead to "irrevocable divestiture of the truster and investiture of the trustee in the trust estate" ${ }^{100}$ This is consistent with property transferring from a party's general patrimony to its trust patrimony. And in Tay Valley the floating charge was granted over property in the chargor's general patrimony (its property and undertaking) and the moving of property into trust was, in patrimonial terms, a transfer like any other. The floating charge could therefore not attach. (As a result, it seems appropriate to characterise such a situation as a Scenario 1 case, in which the same party takes on the roles of both X Ltd (the truster) and Y Ltd (the trustee).)

By contrast, Professor Reid, as well as raising powerful policy and doctrinal objections to the validity of the trust in Tay Valley, has written that the chargeholder (acting through a receiver) should, nevertheless, have prevailed against the beneficiary. ${ }^{101} \mathrm{He}$ argues that a chargeholder is akin to a secured creditor upon attachment, and such a creditor has priority over a beneficiary’s rights. ${ }^{102}$ But, when we apply a patrimonial analysis, it appears that floating charges and fixed securities interact with trust property differently. For example, A Ltd grants a floating charge to B Bank over its whole property and undertaking and then a fixed security over particular property, P, to C Bank. The fixed security gives C Bank a real right in P, while B Bank's floating charge does not. And when the floating charge subsequently attaches it does not attach to P, as P is not in A Ltd's (general) property and undertaking when attachment occurs. As for $\mathrm{C}$ Bank, the fact that its security confers a real right from its creation means that it continues to encumber P when P is “transferred” into A Ltd's trust patrimony. (If A Ltd had granted C Bank's security over the property when it was already in trust, the property would also be encumbered.) ${ }^{103}$ Using the floating charge's attachment effect, as if it were a fixed security, to argue that it should automatically prevail against a beneficiary's right is the incorrect approach. As already stated, the effect of attachment is only relevant if attachment actually takes place.

Since he espoused the views noted above, Professor Reid has helped develop the dual patrimony theory of trusts in Scots law. An apparent implication of this theory is that property moving from one patrimony to another can be considered equivalent to a transfer, as regards the floating charge and the chargor's property and undertaking. If this "pure” form of the dual patrimony approach is not to apply, ${ }^{104}$ explanation is required as to how a floating charge could attach in spite of the property leaving the chargor's general patrimony. It would also need to be considered whether parties such as preferential

\footnotetext{
${ }^{100}$ At 118 .

${ }^{101}$ Reid (n 31) at 115; and see Reid, Property, para 691 n 6.

102 This is correct regarding such security ranking ahead of a beneficiary (see the ranking section below), but does not apply here.

${ }^{103}$ Redfearn v Sommervails (1813) 1 Dow 50 is considered the leading case, although it involved an assignation in security rather than real security.

${ }^{104}$ Gretton \& Steven (n 2) para 23.39, acknowledge that it is debatable whether the transfer from the private patrimony to the trust patrimony is a true transfer.
} 
creditors should receive special protection, even if the debts due to them arose in relation to the chargor's general patrimony. Yet, rather than formulating piecemeal rules, is it not more appropriate to simply establish the circumstances in which a truster-as-trustee trust will be recognised and, where it is so recognised, for the general consequences of transferring property into trust to apply? The current law, on the basis of Tay Valley, is that if property is transferred into a truster-as-trustee trust it will not be attached by a floating charge that was created at an earlier date. The dual patrimony analysis, pushed to its logical "pure" conclusion supports this result.

\section{(5) Enforcement mechanisms}

The Scottish Law Commission has recognised some of the difficulties regarding the attachment and enforcement of floating charges for trust property. In its Report on Registration of Rights in Security by Companies, the Commission noted that trust property is not included in a company's receivership or liquidation, relying on Heritable Reversionary, and therefore it could not ascertain how attachment of a charge would take place. ${ }^{105}$ Furthermore, a chargeholder depends upon a liquidator, receiver or administrator for the realisation of attached property and distribution of proceeds. A floating charge therefore also differs from a fixed security right insofar as the latter can be enforced against particular property in trust, and does not require an insolvency-related process. ${ }^{106} \mathrm{~A}$ reasonable conclusion, given liquidation's potential role in the enforcement of a floating charge, is that the company's property and undertaking must fall within the confines of the property available to the liquidator. As already noted, the exclusion of trust property from the liquidation of a company is not expressly contained in the legislation but is accepted and attested to by case law. ${ }^{107}$ This is also true in English law. ${ }^{108}$ Indeed, one of the fundamental characteristics of a trust, in English law and Scots law, ${ }^{109}$ is that it ring-fences property held in trust from the trustee's private estate in insolvency.

The position for receivership and administration is similar. Although in these situations the floating charge attaches to property "subject to the charge", ${ }^{110}$ this is limited to the property in the company's property and undertaking at the relevant time, due to the content of the creation provision in s 462(1) of the Companies Act 1985. ${ }^{111}$ Therefore, consistency with the position for liquidation

\footnotetext{
${ }^{105}$ Report on Registration (n 8) para 2.31. These issues were not identified in their preceding Discussion Paper on Registration of Rights in Security by Companies (Scot Law Com DP No 121, 2002) para 2.42, where the charging of trust property and accompanying registration were proposed.

106 The processes in which a floating charge is enforced do not necessarily depend upon the insolvency of the debtor company but "insolvency-related process" is a useful shorthand term to include them all. 107 See n 64.

108 See L Tucker et al, Lewin on Trusts, $19^{\text {th }}$ edn (2015) para 22-027, who cite Barclays Bank Ltd v Quistclose Investments Ltd [1970] AC 567 and Re Kayford Ltd [1975] 1 WLR 279 as examples. See also Insolvency Law and Practice: Report of the Review Committee ("Cork Report”) (Cmnd 8558) (1982) paras 1039ff.

${ }^{109}$ For Scots law see e.g. Wilson \& Duncan, Trusts (n 3) paras 1-12ff; Gretton (n 92). For English law, see n 108, e.g. the Cork Report at para 1045.

${ }^{110}$ Insolvency Act 1986 ss 51(1), 53(7), 54(6) and Sch B1 para 115(1B) and (3).

111 The same creation provisions apply; no matter which enforcement method is ultimately used.
} 
regarding the property attached and available for enforcement can be assumed, and is advisable on the grounds of certainty and coherence. There is no apparent reason why the company's "property" in receivership and administration should include trust property when this is not the case for liquidation. ${ }^{112}$ Indeed, Tay Valley ${ }^{113}$ provides that trust property is not subject to a receiver. And there is nothing in the insolvency legislation to support the existence of a parallel liquidation, receivership or administration of the trust patrimony.

All of this represents a considerable challenge to the facilitation of floating charges over trust property. The Scottish Law Commission suggested that the attachment and enforcement of a floating charge over such property would depend upon special provision being made for the winding up of a trust. ${ }^{114}$ Introducing a new trust-specific liquidation process simply to enable the effective charging of trust property would be a drastic and complicated step. The same criticisms would apply to any attempt to construct a separate administration for the trust patrimony. Allowing a receiver to be appointed over trust property would be simpler and more manageable. However, it would be objectionable in policy terms (by giving the chargeholder significant power at the expense of other creditors) and would be at variance with the general prohibition on the appointment of administrative receivers. ${ }^{115}$

Currently, the only insolvency-related process expressly applicable to trust property is sequestration, the default insolvency process in Scots law. The Bankruptcy (Scotland) Act 2016, s 6(1)(a), provides that the trust estate "may be sequestrated" ("in respect of debts incurred by it"). ${ }^{116}$ The trust estate (patrimony) is therefore treated separately from a legal person's general (or private) estate. This means that the property a company holds in trust can be sequestrated, even though its general estate remains untouched by that sequestration. (In fact, a registered company's general estate cannot be sequestrated. ${ }^{117}$ ) At present, sequestration, even of the chargor's trust property, is not an event or process which causes a floating charge to attach and nor does it enable the charge's enforcement. ${ }^{118}$ It is true that if a purported chargeholder were a trust creditor it would have a claim in a sequestration of the trust estate but this would only be a personal unsecured claim for the debt due. The floating charge is a

\footnotetext{
112 See St Clair \& Drummond Young, Corporate Insolvency (n 43) paras 12-02f.

1131987 SLT 207.

${ }^{114}$ Report on Registration (n 8) para 2.31.

115 Insolvency Act 1986 s 72A, as inserted by the Enterprise Act 2002 s 250(1).

${ }^{116}$ In their Report on Bankruptcy and Related Aspects of Insolvency and Liquidation (Scot Law Com No 68, 1981) para 5.5, the Scottish Law Commission considered that the existing law (Bankruptcy (Scotland) Act 1913 s 11, and the earlier cases of J\&W Campbell \& Co (1899) 6 SLT 406; and Bain, Petr (1901) 9 SLT 14) allowed for the sequestration of trust and executor estates. However, they wished to provide a conclusive statement, which led to the Bankruptcy (Scotland) Act 1985 s 6(1)(a) (the predecessor of the same provision in the 2016 Act). As noted in Macleod (n 93) para 3.42, "the fact that a trust can be sequestrated independently of sequestration of any of the trustees also points to the trust being a separate patrimony”.

117 Bankruptcy (Scotland) Act 2016 s 6(2)(a).

${ }^{118}$ It might be problematic if sequestration did cause attachment and enable enforcement, as a trustee in sequestration is not one of the parties that a floating charge would be void against if it was not registered in the charges register: Companies Act 2006 s 859H(3).
} 
statutory creation and without particular legislative provision cannot be recognised as a security to be given priority in a sequestration.

Legislation could, however, provide that the sequestration of a trust estate is an attachment event and that a floating charge would be deemed a security in the sequestration. The absence of control exercisable by a chargeholder in this context, in comparison to receivership and administration, would make this possibility less attractive to lenders, in relative terms. Yet it would minimise changes to the existing law of trusts. Additional provisions would, nevertheless, be necessary to give effect to the prescribed part for unsecured creditors in relation to the trust estate and to make sure that a chargeholder would rank behind preferential trust creditors. Provision could also be made to give a chargeholder a special ground on which to have the trust sequestrated, perhaps along the lines of that available for liquidation, i.e. where a chargeholder's security is "in jeopardy". ${ }^{119}$ And consideration would need to be given to other attachment and ranking issues. ${ }^{120}$

Returning to the current law, one final point regarding enforcement is whether liquidators, receivers and administrators can manage a trust, despite the trust property being technically excluded from the relevant insolvency-related process. If this can be done, could it enable such a party to realise property and distribute proceeds to a chargeholder?

In English law, it is considered possible for a liquidator to administer a trust for an insolvent trustee company. ${ }^{121}$ This applies to administrators too. ${ }^{122}$ Certain commentators suggest that this is also the case in Scots law. ${ }^{123}$ From a property perspective, the position is dubious if the trust property does not fall within the scope of the administration or liquidation. ${ }^{124}$ However, it might be legally justified on the basis that the liquidator has: "Power to do all such other things as may be necessary for winding up the company's affairs and distributing its assets." ${ }^{125}$ And there is a similar provision for administration. ${ }^{126}$ By contrast, it has been held in England that an administrative receiver cannot administer a trust. ${ }^{127}$ As regards Scotland, however, St Clair and Lord Drummond Young suggest that such a party can do so. ${ }^{128}$ In the absence of any justificatory statutory power, and with trust property

\footnotetext{
119 See the Insolvency Act 1986 s 122(2).

${ }^{120}$ See e.g. $n 118$ and the section on ranking $(\mathrm{D}(6))$ below.

121 Tucker et al, Lewin on Trusts (n 108) para 22-018, acknowledge that the reasoning may be "questionable, as the liquidator's duty is to get in and distribute the company's own assets...", but state that "the convenience of the result is obvious".

122 Ibid, para 22-020.

${ }^{123}$ See St Clair \& Drummond Young, Corporate Insolvency (n 43) para 12-25.

${ }^{124}$ As the liquidator or administrator would have no powers over it. There would also be no benefit to the insolvent estate and thus the general body of creditors.

${ }^{125}$ Insolvency Act 1986, Sch 4, para 13. Emphasis added.

${ }^{126}$ Insolvency Act 1986, Sch B1, para 59(1).

127 Tucker et al, Lewin on Trusts (n 108) para 22-021, state that the receiver cannot act as trustee because the trustee's powers are fiduciary and cannot therefore be the subject of a charge: Re William Makin [1993] BCC 453; Buckley v Hudson Forge [1999] PensLR 151; Mettoy Pension Trustees [1990] 1 WLR 1587, particularly at $1616 \mathrm{ff}$.

${ }^{128}$ St Clair \& Drummond Young, Corporate Insolvency (n 43) para 12-25.
} 
being outside the reach of a receiver, it is hard to see how this can be the case; ${ }^{129}$ the directors, acting on behalf of the company, should still have control of any unattached property, such as property held in trust.

In any event, the management of the trust does not benefit the liquidator, administrator or receiver (or the dependent creditors), and they are therefore unlikely to take on such functions. ${ }^{130}$ If they can, and do, administer the trust, the liquidator, administrator or receiver is subject to trustee rights and duties. ${ }^{131}$ This means they must not seek to distribute to a chargeholder without specific authority to do so and the legislation does not presently recognise a floating charge as a security over trust property.

\section{(6) Ranking}

There is always a danger of imprecision when discussing the outcome of competitions between floating charges and competing rights, such as the rights of trustees or beneficiaries. It is necessary to be clear as to whether another right prevails on the basis of non-attachment of the charge or whether it merely ranks ahead. Unlike attachment, which is absolute, ${ }^{132}$ ranking (in its narrow sense) is relative and is dependent upon a charge attaching to the property. The ranking of a charge against competing rights only becomes relevant when the charge attaches to the property and its holder thereby obtains an interest.

Currently, then, the non-attachment of floating charges to trust property means it is unnecessary to consider the rules of ranking and how the rights of a trustee or beneficiary fit with these. If, however, the law was to be reformed to enable floating charges over trust property, attention would need to be given to how a floating charge would rank against other rights. Although there is much about the current ranking provisions for floating charges that could be improved, it would be possible to construct a ranking regime that mirrors the present law (e.g. the Companies Act 1985, s 464, and related provisions). Such a regime would simply apply to the trust patrimony rather than the company's general patrimony. As regards the trust patrimony, the beneficiary's right is merely a personal right and would not be considered a security (fixed or floating) under the ranking provisions for that patrimony. ${ }^{133}$ In fact, a beneficiary only has the right to trust funds remaining after the payment of all trust debts, even unsecured debts. ${ }^{134}$

\footnotetext{
${ }^{129}$ Unless perhaps this is an express power given in the instrument of charge and is allowable by the terms of the trust.

${ }^{130}$ St Clair \& Drummond Young, Corporate Insolvency (n 43) para 12-24f.

${ }^{131}$ Ibid.

${ }^{132}$ I.e. property is either attached or it is not.

${ }^{133}$ To meet the definition of "fixed security" in Companies Act 1985 s 486(1), and Insolvency Act 1986 s 70(1), something must be "an effective security over... property" in a company's winding up.

${ }^{134}$ Lamond's Trustees v Croom (1871) 9 M 662. St Clair \& Drummond Young, Corporate Insolvency (n 43)

para 12-33. In ranking terms, the beneficiary's right is a postponed personal right in relation to the trust patrimony.
} 
St Clair and Lord Drummond Young have contended that a ranking circle of priority would emerge if a floating charge attached to trust property. ${ }^{135}$ They assert that a trust prevails against creditors of the trustee company, including preferential creditors and those who have done diligence, but that these creditors have priority over a chargeholder, who, in turn, would defeat the trust. (It is presumed that their reference to a "trust" is to the right of a beneficiary.) However, under a dual patrimony analysis, the parties mentioned could only all rank against each other if the chargeholder and preferential creditors or diligence creditors had claims in the trust patrimony. If this were so, then the rights of beneficiaries (as postponed creditors) would be defeated by the other parties and the circle would not arise. As such, the suggested circularity problem would not afflict a ranking system for trust patrimonies that mirrors the current system.

With respect to the current law of floating charges and trust law, there is one further rankingrelated matter that must be mentioned. A floating charge attaches to property in the chargor's general patrimony, but what happens if a company subsequently seeks to transfer the property into a trust? Is the "trust property" subject to the charge, which simply ranks ahead of the beneficiaries' rights? St Clair and Drummond Young suggest that the attached floating charge would prevail over an attempt to create a post-attachment trust on the basis of the assignatus utitur jure auctoris principle. ${ }^{136}$ However, it is probably more accurate to state that the charge will have priority because the company's directors will no longer have the power to transfer attached property into a trust; relevant powers will, by that point, be held by a liquidator, receiver, or administrator. Therefore, any attempt by the company's directors to transfer property into a trust will be void and the property will remain in the chargor's general patrimony. ${ }^{137}$

\section{E. CONCLUSION}

A floating charge is an ineffective security as regards trust property in Scots law. As this article has shown, adopting a patrimonial approach to the interpretation of the floating charge legislative provisions appropriately explains why property held by a trustee can never be affected by a floating charge. For property to be within a company's property and undertaking depends upon that property being in the company's general patrimony. And if charged property is moved into a trust patrimony this is treated like any other transfer and so renders a floating charge unattachable. This analysis supports the decision in Tay Valley and provides desirable unity between the property attached by a floating charge and the property that falls within the insolvency-related processes in which the charge attaches and is enforced.

\footnotetext{
135 St Clair \& Drummond Young, Corporate Insolvency (n 43) para 12-03.

${ }^{136}$ Ibid. This Latin maxim is usually used within the context of the assignation of personal rights to mean that all defences that a debtor could use against a cedent are also available against an assignee: see e.g. Anderson, Assignation (n 97) paras 8-01ff.

${ }^{137}$ If the transfer was valid, it could be voidable as a gratuitous alienation.
} 
Using the dual patrimony approach in this context therefore integrates the floating charge with wider Scots law.

As regards potential reform, the charging of trust property no longer seems to be on the Scottish Law Commission's agenda and it is very unlikely that any legislation to reform the law of trusts will make such provision. However, if there was demonstrable demand for change from within the commercial and corporate sectors then the situation could alter. This article has identified certain ways in which the law could be amended to accommodate the charging of trust property. If reform were to take place, the charging of property in a company's general patrimony ought to be distinguished from the charging of property in the company's trust patrimony. To do the latter, a trustee company (e.g. in a Scenario 2 case) should have to create a floating charge expressly over property in a specified trust (of which it is trustee), with public notice being supplied through registration in the charges register. Although this article has shown that there are a number of respects in which constructing a suitable system would be relatively straightforward, especially if there was to be conformity with the dual patrimony analysis and various aspects of the existing law of floating charges, it has also discussed some more challenging issues. The charging of trust property would work most effectively if a trust itself could create a floating charge, rather than a trustee having to do so (either alone or jointly with other trustees). However, conferring something akin to legal personality upon a trust, and concomitant registration against the trust itself, would involve a considerable departure from the existing law. A further issue would be designing an appropriate attachment event and related enforcement mechanism for charges over trust property. It has been suggested that the most sensible option could be to bring floating charges within the ambit of sequestration of trusts. But this would still necessitate a certain amount of legislative amendment and the absence of control for lenders in sequestration could limit its attractiveness.

To some degree then, creating an effective system for the charging of trust property would be onerous and time-consuming. And, as is always the case, the more complex and considerable the required changes, the less likely that such changes will be forthcoming, especially in the absence of overwhelming demand for reform. For trust property and floating charges, this all means that the patrimonial divide separating them is likely to remain an insurmountable obstacle for the foreseeable future. 